\title{
PERAN EKONOMI KREATIF \\ DALAM MENINGKATKAN INDUSTRI PARIWISATA \\ DI SEAWORLD ANCOL
}

\author{
Dewi Retno Dumilah \\ Magister Manajemen, Universitas Mercu Buana \\ 55119110132@student.mercubuana.ac.id \\ Moh. Komarudin \\ Magister Manajemen, Universitas Mercu Buana \\ 55119110105@student.mercubuana.ac.id \\ Rian Ubaidillah \\ Magister Manajemen, Universitas Mercu Buana \\ 55119110083@student.mercubuana.ac.id \\ Sulastri Siagian \\ Magister Manajemen, Universitas Mercu Buana \\ 55119110157@student.mercubuana.ac.id \\ Sugeng Santoso \\ Magister Manajemen, Universitas Mercu Buana \\ sugeng.santoso@mercubuana.ac.id
}

\begin{abstract}
The tourism industry is an industry that can absorb many creative economic markets. The purpose of this paper is to evaluate the creative economic activities as added value that support the tourism industry. The creative economy analyzed here is the creative fashion economy, which is one of the supporters in providing direct income and advertising as a downstream chain of tourism to convey messages to consumers. Method used qualitative and quantitative by looking for regression between income and costs and based on questionnaires conducted on consumers. The results showed a relationship between costs of advertising incurred with income derived from visitor. In a qualitative analysis in the fashion subsector, fashion can contribute a value of 10 $12 \%$ to revenue. To accelerate in this industry is by knowing the various sub-sectors that are part of the tourism industry value chain and increasing creativity and innovation of creative economic products (fashion and advertising).
\end{abstract}

Keywords: creative economy; fashion; tourism industry, advertising; value chain. 


\section{Pendahuluan}

Indonesia memiliki pesona pariwisata yang luas dan besar, dapat dilihat bahwa sejak awal terbentuknya kabinet kerja yang baru, sektor pariwisata begitu digaungkan oleh pemerintah. Bahkan menurut laporan The World Travel and Tourism Council menyatakan bahwa Indonesia adalah negara dengan pertumbuhan pariwisata yang paling bagus jika dibandingkan dengan negara-negara anggota G20 (Widadio, 2014).

Pariwisata memiliki hubungan yang sangat erat dengan rantai nilai kegiatan dimana didalamnya memiliki bermacam usaha yang dapat menyerap pekerja baru sehingga dapat menciptakan lapangan usaha bagi masyarakat. Integritas yang baik dalam rantai usaha kepariwisataan menjadi nilai tambah tersendiri dan merupakan faktor kunci berjalannya industry pariwisata serta dapat memenuhi harapan wisatawan. Karena itu, penguatan antar mata rantai dalam pembentukan industri pariwisata harus dibangun secara kontuinitas sehingga tebentuk integritas yang baik dalam menciptakan produk dan pelayanan yang berkualitas bagi wisatawan (Munaf, 2015).

Menteri Pariwisata dan Ekonomi Kreatif mengatakan, penyatuan kembali Kementerian Pariwisata dengan ekonomi kreatif akan memudahkan pencapaian target bagi dua sektor tersebut. Melalui penggabungan dan penyatuan tersebut diharapkan sektor pariwisata akan lebih kuat karena hasil dari bidang kreatif dapat mendukung sektor pariwisata dan sebaliknya (Kustiani, 2019). Ekonomi Kreatif (Ekraf) saat ini juga merupakan salah satu sektor yang diharapkan mampu menjadi kekuatan baru ekonomi nasional yang berkelanjutan dan dapat menekankan pada penambahan nilai barang lewat daya pikir serta kreativitas manusia. Ekonomi Kreatif-pun telah menjadi salah satu katalisator pertumbuhan ekonomi Indonesia di tengah perlambatan pertumbuhan ekonomi global (Munaf, 2019). 
Salah satu industri pariwisata yang tidak terlepas dari pentingnya manajemen rantai pasok adalah Taman Impian Jaya Ancol yang mengelola sejumlah unit bisnis yang berada di kawasan Ancol Taman Impian, seperti: Dunia Fantasi, Ocean Dream Samudera, Atlantis Water Adventures, Sea World Ancol, Taman Impian, Putri Duyung Ancol dan Allianz Ecopark serta penjualan merchandise. Salah satu unit rekreasinya yaitu Sea World Ancol secara penuh diambil alih Perseroan sejak 10 Juli 2015 (Pembangunan Jaya Ancol, 2019).

Mengacu pada penjelasan-penjelasan di atas, penelitian ini dimaksudkan untuk menganalisa kegiatan rantai nilai (value chain) pada produk ekonomi kreatif yang menunjang pariwisata Sea World Ancol, mengidentifikasi aktivitas ekonomi kreatif yang mempunyai nilai tambah (value added) tertinggi terhadap kegiatan unit, mengembangkan analisis yang menggambarkan masalah yang dihadapi ekonomi kreatif yang terlibat dalam rantai nilai dan solusi penyelesaiannya, mengevaluasi posisi dan kontribusi untuk meningkatkan pendapatan unit, serta menawarkan kesimpulan yang dapat dirumuskan di sekitar strategi yang dapat digunakan untuk akselerasi kemitraan dengan ekonomi kreatif dalam rantai nilai ini.

\section{Teori}

Sektor pariwisata telah membuktikan sebagai core economy pembangunan nasional, sektor pariwisata Indonesia memiliki keunggulan kompetitif dan keunggulan komparatif, antara lain sebagai penghasil devisa terbesar dimana pada tahun 2019 industri pariwisata diproyeksikan menjadi penghasil devisa terbesar yaitu USD 24 miliar, menjadi salah satu yang terbaik di regional dimana pariwisata Indonesia menjadi salah satu negara dengan pertumbuhan pariwisata terbaik di kawasan regional selama empat tahun terakhir, serta pada Travel and Tourism Competitiveness Index Report pada tahun tahun 2017 peringkat Indonesia ada pada peringkat 42, dan terakhir tahun 2019 naik ke peringkat 40 (Sutono, et.al, 2019). 
Konsep Pariwisata memiliki kerangka multidimensi bagi setiap orang. Konsep ini kemudian bisa ditambahkan dengan fitur yang bisa menambahkan value bagi perkembangan parwisata agar menarik. Atas dasar itu, maka perlu integrasi dengan subsektor lain sebagai pendongkrang value added pariwisata. Keterkaitan dan sinergi baru dengan pariwisata juga muncul bersamaan, menawarkan potensi besar untuk menumbuhkan permintaan dan mengembangkan produk, pengalaman, dan pasar baru (OECD, 2014).

Secara ekonomi terlihat bahwa sektor pariwisata memberikan kontribusi nyata dalam perolehan devisa negara, pendapatan asli daerah dan juga pendapatan masyarakat yang tercipta dari usaha-usaha kepariwisataan yang dikembangkan, serta membuka lapangan kerja dan penyerapan tenaga kerja yang tinggi (Sutono, et.al. 2019).

Sektor pariwisata memiliki rantai nilai yang luas sehingga mampu menciptakan lapangan usaha baru yang dapat diintegrasikan untuk memberikan nilai lebih dan memenuhi harapan wisatawan selaku konsumen. Keterkaitan dan sinergi setiap mata rantai usaha pada sektor pariwisata menjadi hal yang perlu dikembangkan secara kontinuitas agar pariwisata dapat begerak secara signifikan baik (Munaf, 2015).

Pariwisata akan terus tumbuh jika didukung oleh pertumbuhan ekonomi kreatif. Ekonomi kreatif telah mengambil peran penting selama periode dua dekade terakhir dan dibutuhkan pengetahuan dan keterampilan yang lebih baik agar dapat memiliki dampak ekonomi yang substansial (OECD, 2014).

Seiring lahirnya Perpres Nomor 69 Tahun 2019 tentang Kementerian Pariwisata dan Ekonomi Kreatif, Badan Ekonomi Kreatif kini lebur dengan Kementerian Pariwisata. Diharapkan ekonomi kreatif mampu meningkatkan kualitas kepariwisataan menjadi daya tarik di destinasi pariwisata, serta menjadi media 
promosi bagi kepariwisataan. Sebaliknya dengan adanya kemajuan pariwisata suatu destinasi akan diikuti dengan peningkatan permintaan akan karya kreatif. Dengan adanya promosi pariwisata juga dapat mengangkat keunggulan karya kreatif suatu destinasi (Saputra, 2019).

Mengembangkan pariwisata kreatif memiliki implikasi bagi administrasi pariwisata nasional, otoritas pariwisata regional dan organisasi pemasaran tujuan. Tantangannya bukan hanya untuk memahami industri kreatif dan bagaimana hubungan ini dengan pariwisata, tetapi untuk menghargai perubahan mendasar yang didorong oleh pertumbuhan ekonomi kreatif (OECD, 2014).

Ekonomi kreatif memiliki keterikatan penuh terhadap industri kreatif, namun dengan cakupan yang lebih luas jika dibandingkan dengan industri kreatif. Ekonomi kreatif dipandang sebagai suatu ekosistem dimana di dalamnya terdapat hubungan saling bergantung di antara rantai nilai kreatif (creative value chain), lingkungan pengembangan (nurturance environment), pasar (market) dan dokumentasi (archiving). Tidak hanya penciptaan nilai tambah secara ekonomi, namun ekonomi kreatif juga dapat meningkatkan daya saing, selain itu juga nilai tambah sosial, budaya dan lingkungan. Selain meningkatkan daya saing, ekonomi kreatif juga bisa meningkatkan kualitas hihup Bangsa Indonesia (Kementerian Pariwisata dan Ekonomi Kreatif RI: 2014). Konsep rantai nilai sendiri mengacu pada semua kegiatan yang menambah nilai pada produk atau layanan melalui berbagai tahap produksi, mulai dari desain, pengembangan, bahan baku dan input, pemrosesan hingga kegiatan pemasaran dan pasca-penjualan (APEC, 2019).

Di dalam Peraturan Presiden Nomor 72 Tahun 2015, produk-produk ekonomi kreatif diklasifikasikan kedalam 16 subsektor yang oleh Badan Pusat Statistik (BPS) kemudian dirinci ke dalam 206 Klasifikasi Baku Lapangan Usaha Indonesia (KBLI) 5 digit. Rincian keenam belas subsektor ekonomi kreatif berturut-turut sesuai dengan 
urutan KBLI adalah Arsitektur, Desain Interior, Desain Komunikasi Visual, Desain Produk, Film, Animasi, dan Video, Fotografi, Kriya, Kuliner, Musik, Fesyen, Aplikasi dan Game Developer, Penerbitan, Periklanan, Televisi dan Radio, Seni Pertunjukan, Seni Rupa (Bekraf, 2017).

Tingkat keterkaitan antar industri akan memberikan indikasi bagi pembuat kebijakan dalam mengembangkan industri-industri yang mampu menjadi sektor kunci dalam mata rantai kegiatan produksi. (Kuswara, et.al., 2014)

Orientasi proses manajemen rantai suplai telah ditekankan sebelum dan sejak Porter memperkenalkan rantai nilai, sebuah paradigma telah dikembangkan dalam bidang ekonomi bahwa manajemen berorientasi pada proses mengarah pada hasil yang unggul dibandingkan dengan fokus tradisional pada fungsi. Saat menganalisis sebuah rantai maka pemodelan proses merupakan landasan pertama yang penting (Stadler \& Kilger, 2015).

Istilah rantai nilai sendiri menggambarkan konsep bahwa ketika produk atau layanan bergerak melalui masing-masing tahap produksi maka nilai ditambahkan sepanjang jalan. Nilai ini dapat ditangkap dalam satu aktor tunggal (dalam kasus rantai terintegrasi secara vertikal), atau mungkin melibatkan sejumlah aktor pada setiap tahap. Nilai relatif dari setiap tahap tidak akan sama, dan oleh karena itu salah satu tantangan utama untuk perusahaan dan pekerja adalah bagaimana untuk memposisikan diri dalam kegiatan yang memiliki nilai tambah tertinggi, dan bagaimana memaksimalkan nilai yang ditangkap dalam tahap tersebut pada posisi di mana mereka dapat berpartisipasi (World Bank Group, 2018).

Berdasarkan data dari dinas pariwisata DKI Jakarta bahwa Badan Pusat Statistik Provinsi DKI Jakarta mencatat dari 14 objek wisata unggulan, dari 2013 sampai 2017 dimana lokasi atau objek wisata Taman Impian Jaya Ancol selalu menempati tingkat teratas kunjungan wisatawan. Obyek wisata unggulan yang 
paling banyak dikunjungi wisatawan adalah Taman Impian Jaya Ancol sebanyak 19,26 juta orang $(57,69$ persen) dari total pengunjung sebanyak 33,38 juta orang di tahun 2017 (Pardosi, 2018).

PT Taman Impian Jaya Ancol (“TIJA”) merupakan entitas anak Perseroan yang resmi beroperasi di tahun 1972 dan bergerak di bidang usaha rekreasi, resor, jasa dan perdagangan. Pada pelaksanaannya, TIJA bertanggung jawab dalam mengelola sejumlah unit bisnis yang berada di kawasan Ancol Taman Impian, seperti Dunia Fantasi, Ocean Dream Samudera, Atlantis Water Adventures, Sea World Ancol, Taman Impian, Putri Duyung Ancol dan Allianz Ecopark serta penjualan merchandise. Salah satu unit rekreasi di Kawasan Taman Impian Jaya Ancol adalah Sea World Ancol, Sea World Ancol secara penuh diambil alih Perseroan sejak 10 Juli 2015, sebelumnya area rekreasi ini dikelola dengan sistem Built-Operate-Transfer (BOT) bersama mitra strategis Perseroan (Pembangunan Jaya Ancol, 2018).

Berdasarkan Peraturan Kepala Badan pusat Statistik No.19 Tahun 2017 tentang Klasifikasi Baku Lapangan Usaha Indonesia (KBLI) untuk upaya penyeragaman konsep, definisi dan klasifikasi lapangan usaha maka Taman Impian jaya Ancol termasuk ke dalam kategori Kawasan pariwisata dengan kode 68120.

Yang termasuk dalam kelompok kawasan pariwisata yaitu mencakup pengusahaan lahan dengan luas minimal 100 hektare dengan mengatur dan membagi menjadi unit-unit tertentu, membangun atau menyewakan unit-unit, untuk dapat dibangun sarana dan prasarana wisata, dan kebutuhan lain yang diperlukan dengan persyaratan yang dipersiapkan sebelumnya, serta menyediakan tempat untuk pengurusan keperluan administrasi usaha Kawasan pariwisata (Rahmah, 2019). Klasifikasi dari unit usaha atau keigiatan usaha barang/jasa yang dihasilkan merupakan Klasifikasi Baku Lapangan Usaha Indonesia (KBLI) (Utoyo \& Sutarsih, 2017). 
Ketika sebuah perusahaan bergerak menuju integrasi yang lebih besar pada kontinum make-or-buy, bentuk organisasi selanjutnya adalah aliansi strategis. Aliansi strategis adalah pengaturan sukarela antara perusahaan yang melibatkan berbagi pengetahuan, sumber daya, dan kemampuan dengan maksud mengembangkan proses, produk, atau layanan. Aliansi strategis juga dapat memfasilitasi investasi dalam aset spesifik transaksi tanpa menghadapi biaya transaksi internal yang terlibat dalam memiliki perusahaan pada berbagai tahap rantai nilai industri. Aliansi strategis sendiri adalah istilah umum yang menunjukkan berbagai bentuk organisasi hybrid, di antaranya adalah kontrak jangka panjang, aliansi ekuitas, dan usaha patungan (Rothaermel, 2017).

Model Competitiveness Diamond Porter (1990), mengungkapkan bahwa industri di wilayah yang unggul bukan dari kesesuaian sendiri namun merupakan keberhasilan kelompok dengan keterkaitan antara perusahaan \& lembaga yang mendukung. Dalam kelompok industri, perusahaan yang terlibat adalah perusahaan besar, menengah, dan juga perusahaan kecil oleh karena itu diperkenalkan dengan teori kemampuan kompetitif suatu negara yang diilustrasikan dalam model berlian seperti terlihat pada gambar 1 .

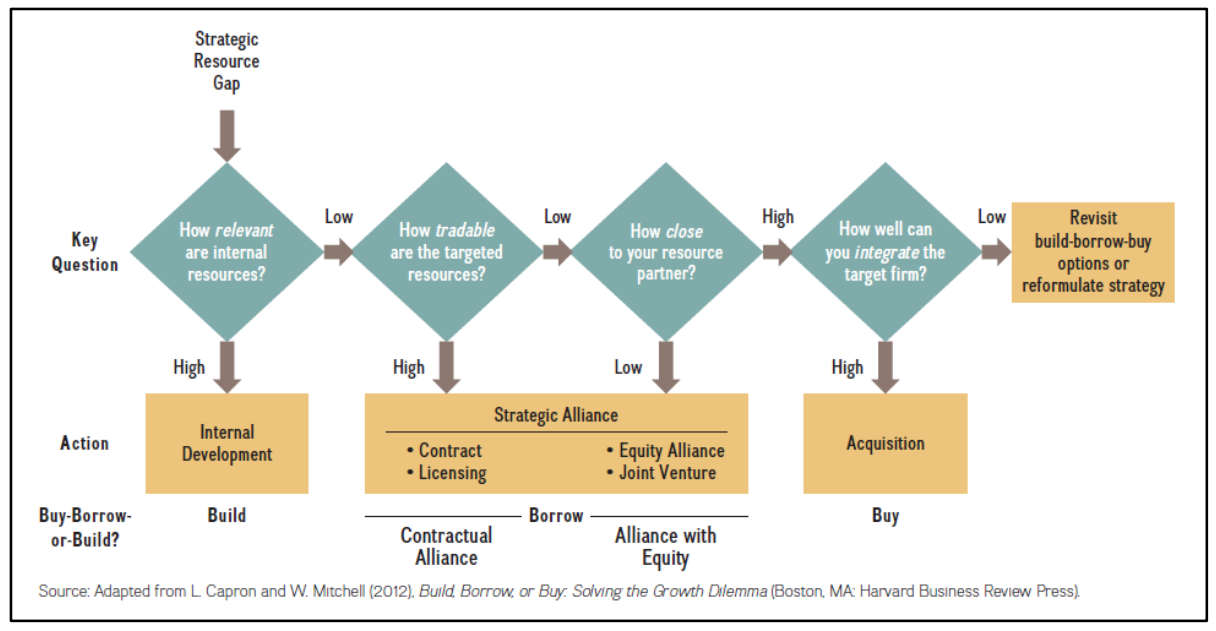

Gambar 1. Panduan Strategi Perusahaan Potter

Sumber: Rothaermel (2017) 


\section{Metode}

Metode pendekatan kualitatif dan kuantititatif digunakan untuk menganalisa rantai nilai. Data yang digunakan terdiri dari data primer dari kuisioner yang diberikan kepada pengunjung serta data sekunder dari laporan pendapatan dan realisasi pengeluaran untuk iklan (Selling Expence) unit rekreasi Sea World Ancol selama periode $2015-2019$.

Analisis kuantitatif yang digunakan adalah dengan Uji Koefisien Korelasi untuk mengukur seberapa besar tingkat keeratan hubungan antara Biaya yang dikeluarkan untuk menggunakan jasa periklanan dengan pendapatan industri pariwisata. Hasil survei terhadap pengunjung yang membeli produk merchandise dan sumber mencari iklan menjadi data primer pada penulisan ini. Hasilnya akan ditampilkan dalam korelasi sederhana dan kesimpulan kuisioner.

\section{Pembahasan}

Untuk melihat bagaimana keterkaitan aktivitas ekonomi kreatif pada rantai nilai di Sea World Ancol sebagai industri pariwisata maka dibuatlah dengan membuat rangkaian aktivitas operasional Sea World Ancol, sehingga diperoleh gambaran rantai nilai antara industri pariwisata dengan menjadikan ekonomi kreatif sebagai aktivitas sekundernya. Dalam gambaran skematik gambar 2 diperolehlah juga berbagai aktivitas-aktivitas pendukung untuk mendapatkan nilai tambah. Melalui rangkaian rantai nilai tambah maka dapat dievaluasi dan dipahami peran dari masing-masing aktivitas pada rantai nilai tersebut untuk dapat memberikan peningkatan nilai tambah pada industri. Seperti apa yang tertulis dalam kajian World Bank Group (2018), bahwa peta rantai nilai menggambarkan pelaku yang membawa produk dari bahan baku sampai konsumsi akhir. Peta rantai nilai adalah alat yang berguna untuk memandu penelitian. 
Berdasarkan sketsa rantai nilai pada Gambar 2, ternyata ditemukan 8 subsektor ekonomi kreatif, yaitu Seni Pertunjukan, Game Developer, Arsitektur, Fesyen, Desain Produk, Desain Komunikasi Visual, Periklanan, TV dan Radio yang menjadi bagian dari nilai tambah industri pariwisata salah satu unit rekreasi di Taman Impian Jaya Ancol ini, dan dengan mendetailkan rantai nilai yang dibuat, diperoleh sekitar 29 KBLI 5 digit.

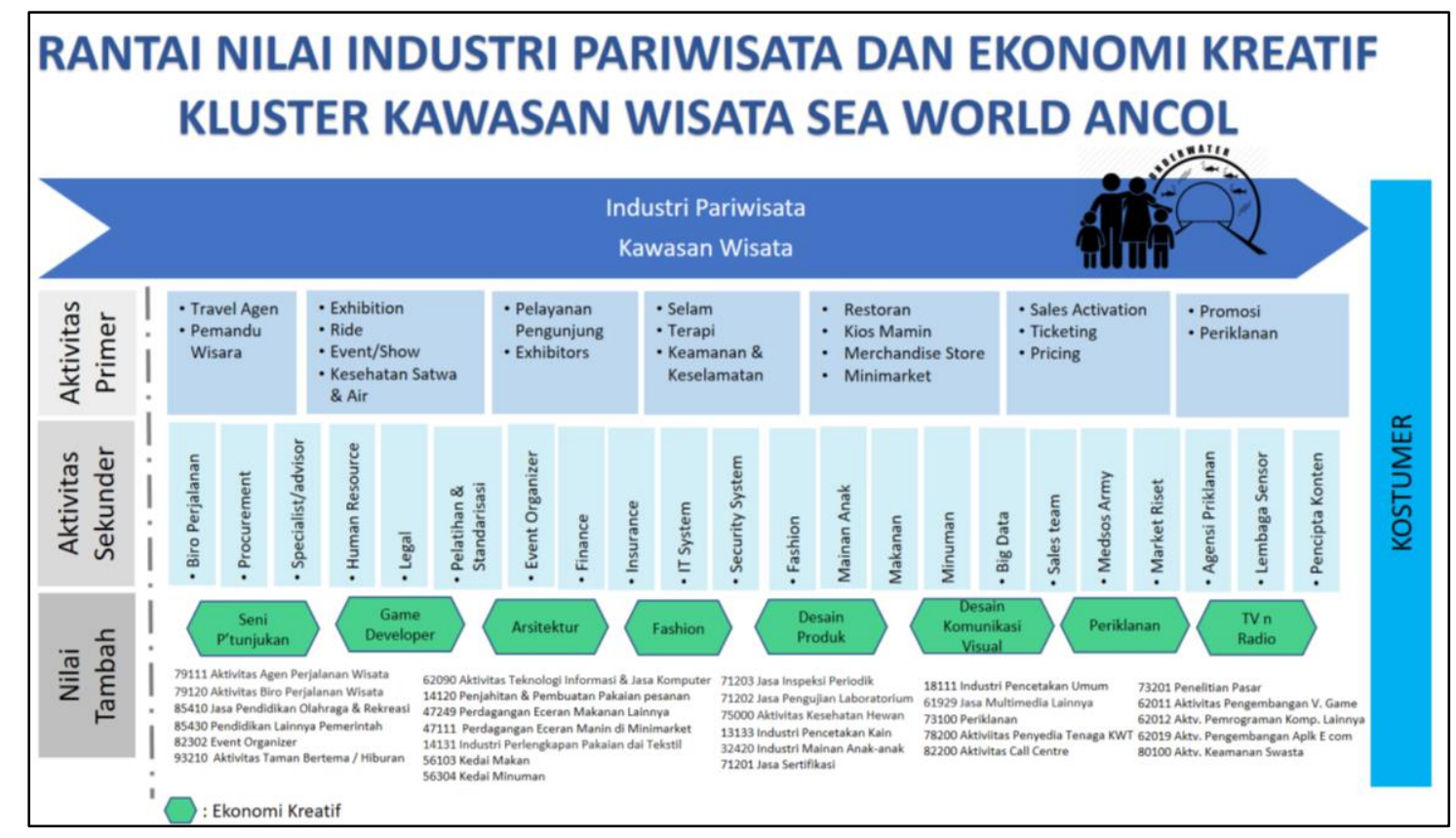

Gambar 2. Pemodelan Rantai Nilai Industri Pariwisata dan Ekonomi Kreatif Sub Sektor SeaWorld Ancol Sumber: Olahan Data Peneliti (2020)

Oleh karena itu dengan rantai nilai yang terbentuk dapat dikatakan bahwa dari satu industri pariwisata ternyata dapat menciptakan berbagai aktivitas yang mempengaruhi rantai nilai dan dari berbagai aktivitas tersebut dapat di analisa lebih lanjut agar peningkatan rantai nilai tambah dapat tercapai. Dilihat kedepannya, dengan pemodelan pada Gambar 2 yang menunjukkan terkaitnya subsektor ekonomi kreatif dan KBLI, maka hal tersebut mendukung adanya kemungkinan penambahan PDB. 
Sesuai dengan Rencana Strategis Badan Ekonomi Kreatif yaitu pertumbuhan PDB Ekonomi kreatif ditentukan oleh jumlah unit usaha ekonomi kreatif dimana semakin banyak jumlah usaha semakin besar kapasitas menghasilkan nilai tambah ekonomi dan besarnya nilai tambah per perusahaan atau produktivitas usaha kreatif (Munaf, 2017).

Sebagaimana diketahui dalam indutri pariwisata produk yang dihasilkan bersifat intangible di mana jasa pelayann adalah keutamaannya, sedangkan dari penggambaran rantai nilai maka aktifitas yang membawa barang dan mencapai konsumen dalam bentuk barang adalah produk-produk yang di jual di toko merchandise.

Oleh karena itu dengan menganalisa dan mengevaluasi pendapatan dari hasil penjualan barang merchandise menjadi penting karena selain nilai tambah bagi kegiatan utama, analisis rantai dari merchandise merupakan keterlibatan ekonomi kreatif dengan KBLI yang cukup penting.

Tabel 1. Pendapatan dan Pengeluaran Sea World Ancol

\begin{tabular}{|l|l|l|l|l|l|}
\hline & 2015 & 2016 & 2017 & 2018 & 2019 \\
\hline $\begin{array}{l}\text { Pendapatan } \\
\text { Total }\end{array}$ & 40.046 .533 .648 & 94.850 .217 .456 & 109.263 .401 .354 & 116.304 .020 .957 & 133.632 .299 .176 \\
\hline $\begin{array}{l}\text { Pendapatan } \\
\text { Tiket dan } \\
\text { lainnya }\end{array}$ & 36.129 .554 .572 & 83.089 .515 .899 & 97.938 .832 .798 & 105.080 .621 .541 & 120.489 .436 .123 \\
\hline $\begin{array}{l}\text { Penjualan } \\
\text { Merchandise }\end{array}$ & 3.916 .979 .076 & 11.760 .701 .557 & 11.324 .568 .556 & 11.223 .399 .416 & 13.142 .863 .053 \\
\hline $\begin{array}{l}\text { Selling } \\
\text { Expense }\end{array}$ & -120.616 .420 & -748.313 .975 & -4.081 .463 .846 & -3.336 .446 .699 & -4.501 .348 .669 \\
\hline
\end{tabular}

Sumber: Laporan Keuangan Internal SeaWorld Ancol 
Jika dilihat dari besarnya nilai tambah penjualan merchandise terhadap pendapatan total maka nilainya dalam kisaran 10\% sampai dengan $12 \%$ dari total pendapatan. Walaupun hanya $10 \%$ sampai $12 \%$, namun demikian penjualan merchandise merupakan penyumbang terbesar setelah pendapatan dari penjualan tiket pengunjung.

Pada penelitian ini, subsektor fesyen menjadi sorotan dikarenakan memiliki potensi besar lain yang dapat tercipta dari kegiatan ini dan dapat dikatakan paling dekat dengan kreativitas dan tema pada industri pariwisata. Sebelum analisis mengenai merchandise, hal yang dilakukan adalah mendapatkan data primer melalui survei kepada pengunjung untuk mengetahui jenis merchandise yang dibeli saat berkunjung ke unit rekreasi dan alasan membeli produk tersebut.

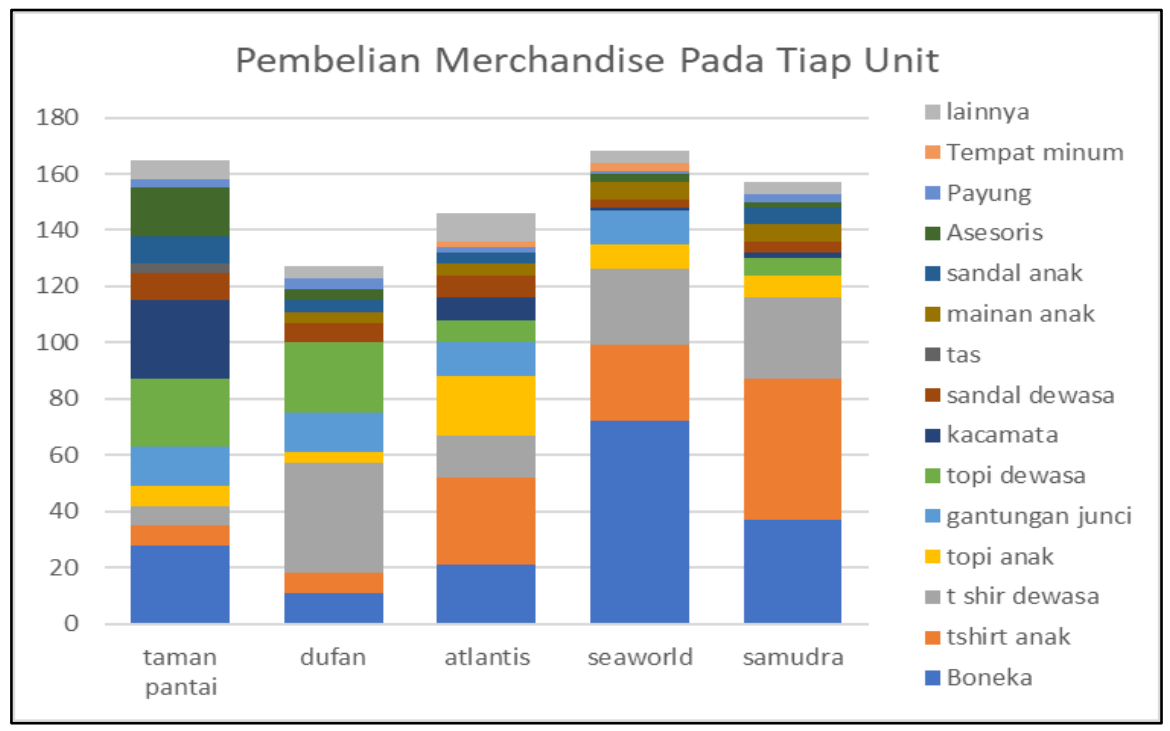

Gambar 3. Grafik Hasil Pengolahan Survei Pembelian Produk Mechandise Sumber: Olahan Data Peneliti (2020)

Gambar 3 menunjukan hasil survei pembelian produk merchandise dan dari hasil survei keseluruhan di Ancol diperoleh bahwa sebagian besar yang di beli adalah kategori t-shirt atau kaus serta beberapa kategori barang yang dibeli yang ternyata dapat dikelompokkan berdasarkan penjelasan aktifitas ekonomi kreatif ke dalam 
subsektor fesyen. Pengelompokan produk merchandise yang dijual dan dapat dimasukkan kedalam kategori barang hasil fesyen terdiri dari kaus, topi, asesoris.

Seperti yang dikategorikan dalam KBLI Industri Pakaian jadi dimana Golongan pokok ini mencakup semua pekerjaan menjahit (baju siap pakai atau berdasarkan ukuran/pesanan), dalam semua bahan (seperti kulit, bahan baju, bahan rajutan atau tenunan dan lain-lain), dari semua jenis pakaian (seperti pakaian luar, pakaian dalam pria, wanita atau anak-anak, pakaian kerja dan pakaian santai dan lain-lain) dan asesoris, tidak ada perbedaan dalam pembuatan baju untuk anak-anak dan untuk orang dewasa, atau antara pakaian tradisional dengan pakaian modern (BPS, 2019).

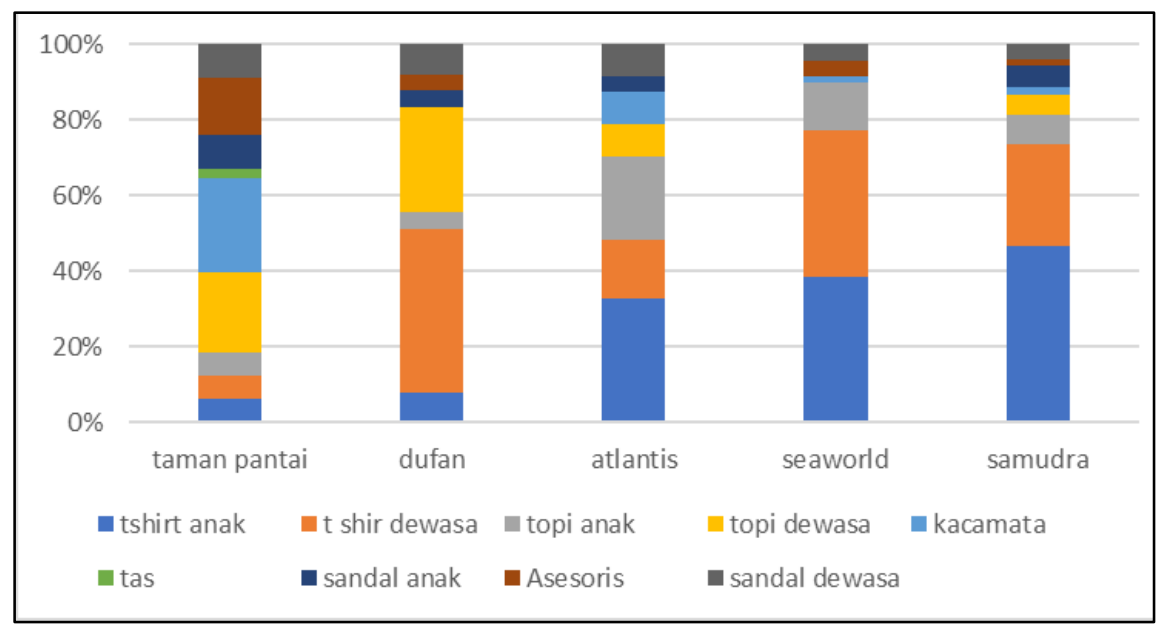

Gambar 4. Grafik Proporsi Peminatan Pembelian Produk Atribut Fesyen Sumber: Olahan Data Peneliti (2020)

Data pada gambar 4 di atas menandakan bahwa, produk fesyen menjadi pilihan utama pengunjung saat membeli produk merchandise. Hal tersebut menandakan masih adanya kesesuai dari data jumlah usaha/perusahaan ekonomi kreatif berdasarkan hasil Listing Sensus Ekonomi tahun 2016 dimana dari 8.203.826 usaha ternyata didominasi oleh 3 subsektor yaitu kuliner $(67,66 \%)$, fesyen $(15,01 \%)$, dan kriya (14,56\%) (Utoyo \& Sutarsih, 2017). 
Dari data diatas, hal yang sama berlaku pada dunia pariwisata. Namun jika menjeneralkan pencapaian atau nilai yang dapat diberikan ekraf fesyen seharusnya pendapatan dari penjualan merchandise dapat ditingkatkan sampai $15 \%$. Namun jika melihat dari hasil penjualan produk ternyata masih tergolong kecil dan stagnan pada tingkat $10 \%$ pertahunnya. Dari pertimbangan tersebut maka survei kepada pengunjung terhadap alasan membeli produk merchandise dilakukan.

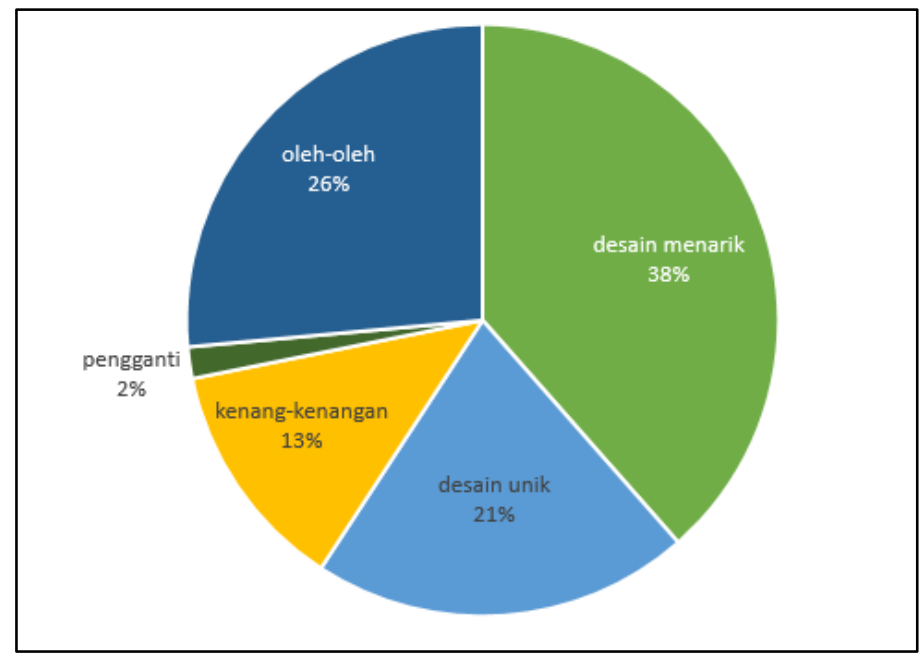

Gambar 5. Hasil Survei Alasan Membelian Produk Merchandise Sumber: Olahan Data Peneliti (2020)

Berdasarkan survei yang dilakukan terhadap "alasan membeli produk" tersebut ternyata 39\% menyatakan membeli karena alasan desain yang menarik dan $21 \%$ karena desain yang unik sesuai demgan tempat pariwisata. Agar tercipta akselerasi antara rantai nilai fesyen dan pariwisata dari hasil survei dimana pengunjung membeli produk dikarena alasan desain yang unik dan menarik tersebut, maka pertimbangan yang dapat dijadikan masukan adalah pemasok produk fesyen harus memberikan banyak alternatif dan desain yang unik serta menarik dengan menyesuaikan keinginan target market. Seperti penelitian yang dilakukan Simanjuntak (2017) untuk Bekraf yang menyatakan bahwa pelaku industri kreatif juga perlu melakukan identifikasi detail atau gambaran momen kebutuhan khusus 
target konsumen dalam melakukan pembelian melalui riset pemasaran yang memadai.

Dengan menghitung harga dari pemasok dan harga jual produk di dalam toko dapat terlihat nilai tambah untuk aktivitas ekonomi kreatif ini dapat mencapai angka yang cukup besar dikarenakan perlakuan pada proses menetapan harga jual yaitu dengan meningkatkan harga dari produsen sekitar $61 \%$ dan dijual ke konsumen dengan nilai tambahan mencapai $128 \%$. Peningkatan nilai tambah tersebut dikarenakan juga saat di toko merchandise, produk tersebut diberikan brand atau merek Sea World Ancol yang menjadikan nilai jual produk akan meningkat. Berdasarkan Direktorat Jenderal Kekayaan Intelektual bahwa salah satu pemakaian merek adalah sebagai alat promosi, jaminan atas mutu barangnya dan penunjuk asal barang (DGIP, 2019)

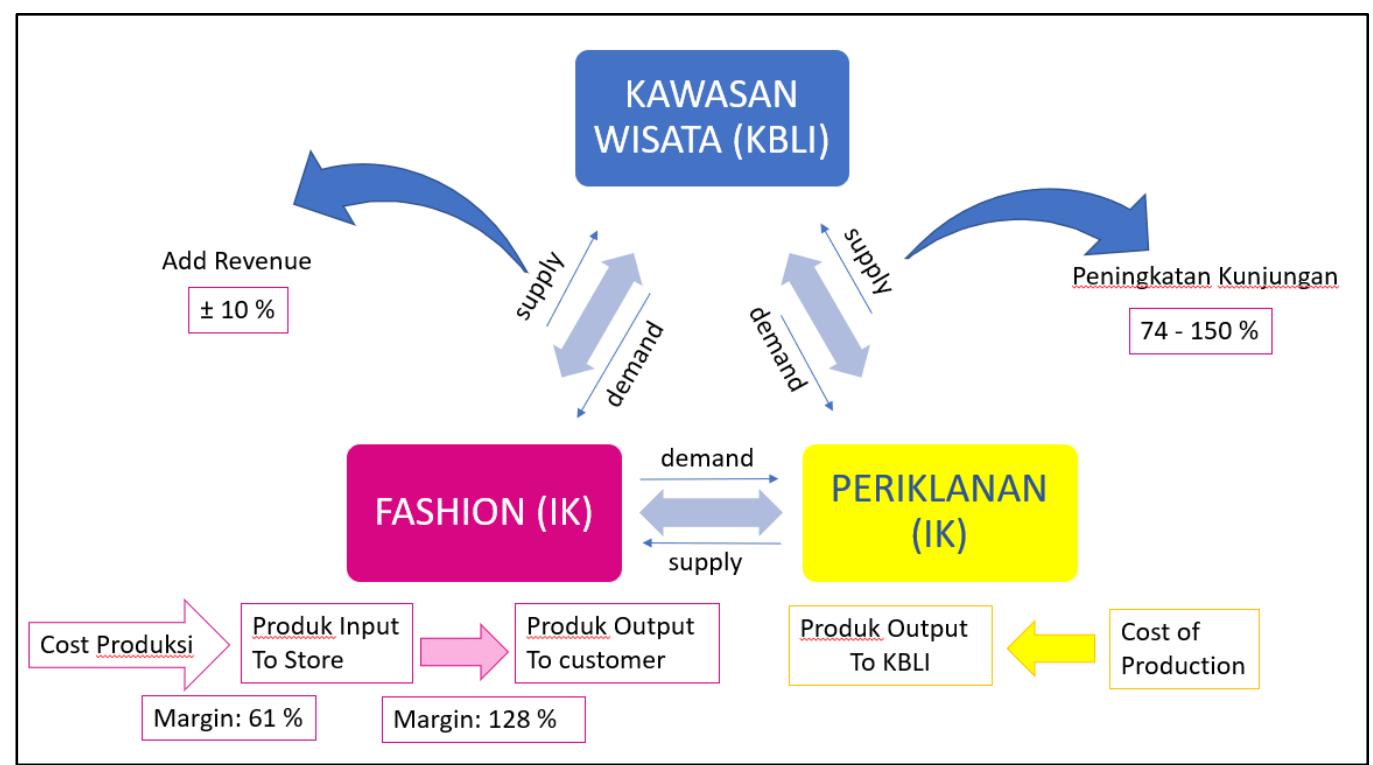

Gambar 6. Sketsa Analisa dan Perhitungan Nilai Tambah Kegiatan Ekonomi Kreatif Pada Pendapatan

Sumber: Olahan Data Peneliti (2020) 
Setelah membahas input ekonomi kreatif yang memberikan efek langsung pada pendapatan, dalam industri pariwisata ada delivery produk yang harus disampaikan kepada khalayak luas. Metode yang ditempuh untuk penyampaian produk kepada masyarakat, umumnya dilakukan bentuk materi promosi dan iklan. Sea World Ancol mengalokasikan anggaran khusus untuk promosi dan periklanan, bentuknya antara lain dengan teaser film, video klip, dan pemasangan pada iklan atau promosi luar ruangan atau ruang publik.

Tujuannya sendiri seperti yang dikemukanan oleh Rowley (1998) dalam Simanjuntak (2017) bahwa promosi merupakan bagian dari strategi dan taktik komunikasi yang diterapkan oleh perusahaan untuk memastikan konsumen memahami produk dan jasa yang ditawarkan oleh perusahaan. Tujuan dari promosi adalah untuk meningkatkan kinerja penjualan dengan memperbaiki brand recognition, membangun iklim pasar yang sesuai untuk penjualan di masa mendatang, mengedukasi pasar, serta membangun keungulan kompetitif produk atau layanan.

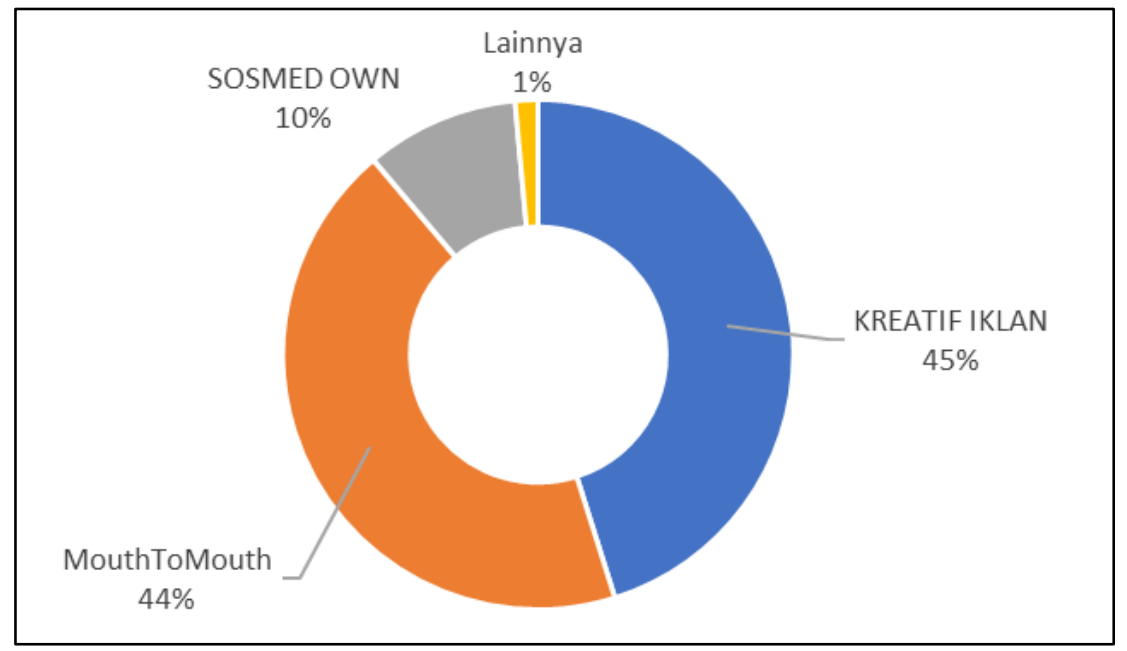

Gambar 7. Grafik Hasil Survei Sumber Informasi Iklan Diperoleh Pengunjung Sumber: Olahan Data Peneliti (2020) 
Berdasarkan pengelompokan hasil survei dengan menanyakan sumber informasi iklan yang diperoleh pengunjung sebelum datang, didapatkan iklan dengan berbagai kreatifitasnya masih menjadi alternatif yang tepat untuk mencapai masyarakat.

Dengan menghitung besarnya pendapatan dan pengeluaran untuk promosi setiap tahunnya, lalu menguji dengan Uji Korelasi Pearson di dapatkan hasil dengan nilai r cukup besar, yaitu 0,972 yang menandakan korelasi yang sangat kuat antara hubungan peningkatan pendapatan total dengan besarnya anggaran yang dikeluarkan. Hubungan korelasi inilah yang menandakan bahwa adanya iklan atau promosi sangat penting untuk mencapai target market.

Tabel 2. Hasil Uji Korelasi Pendapatan Total dengan Pengeluaran Promosi/Iklan

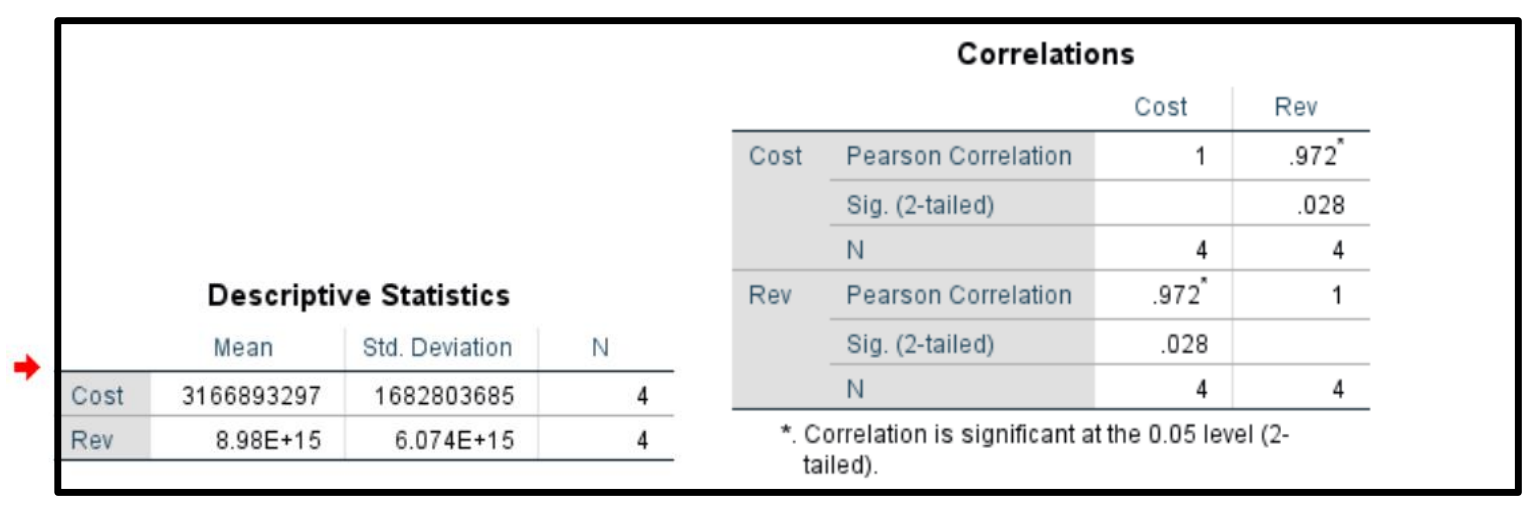

Sumber: Olahan Data Peneliti (2020)

Sedangkan dengan melihat tanda satu bintang maka signifikansi sebesar 0,05, dimana $0.028<0.05$ berarti korelasi yang cukup kuat terjadi antara pengeluaran untuk promosi (cost) dengan pendapatan rekreasi (revenue) namun tidak signifikan. Hal tersebut dapat dilihat dengan menggunakan data perbulan selama 2015 - 2019 perhitungan perolehan pendapatan dan pengeluaran biaya iklan, ternyata naik atau publish-nya iklan pada bulan tertentu tidak langsung berdampak pada peningkatan pengunjung. 


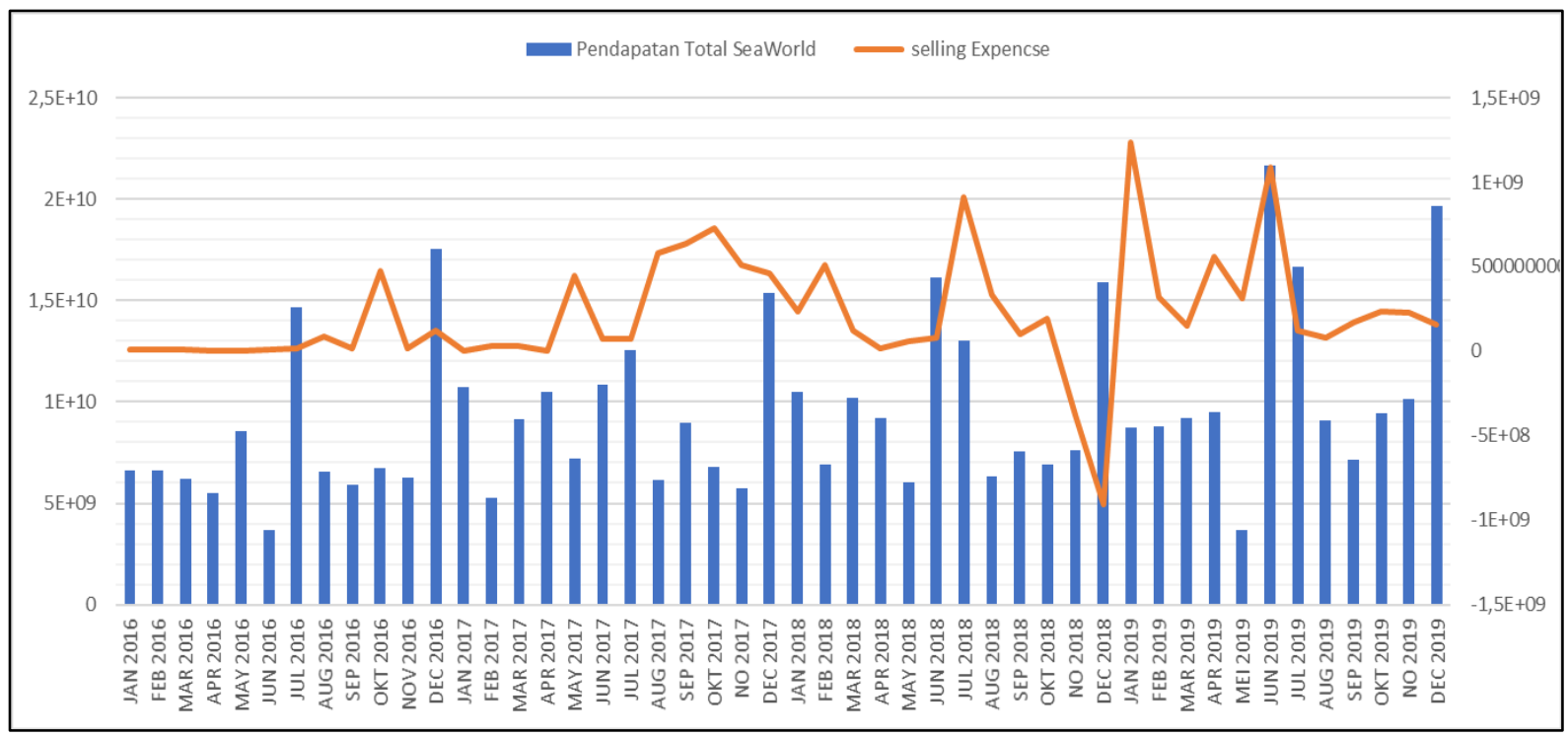

Gambar 8. Grafik Perbandingan Selling Expence Dengan Capaian Pendapatan Sumber: Olahan Data Peneliti (2020)

Dalam grafik terlihat bahwa kecenderungan yang terjadi adalah pengunjung Sea World Ancol akan berkunjung menunggu sampai dengan momen liburan sekolah atau hari raya sebagaiman yang terlihat pada grafik pada bulan Juli dan Desember 2016 dan 2017, Juni dan Desember 2018 dan 2019 dimana pada periode tersebut adalah bulan dimana terdapat liburan sekolah, hari raya dan liburan akhir tahun.

Berdasarkan data primer juga diperoleh bahwa untuk unit Sea World Ancol para pengunjung sebagian bear memperoleh informasi melalui web, untuk iklan komersial melalui televisi dan billboard yang mengambil anggaran terbesar justru berada di angka kurang dari 15\%. 


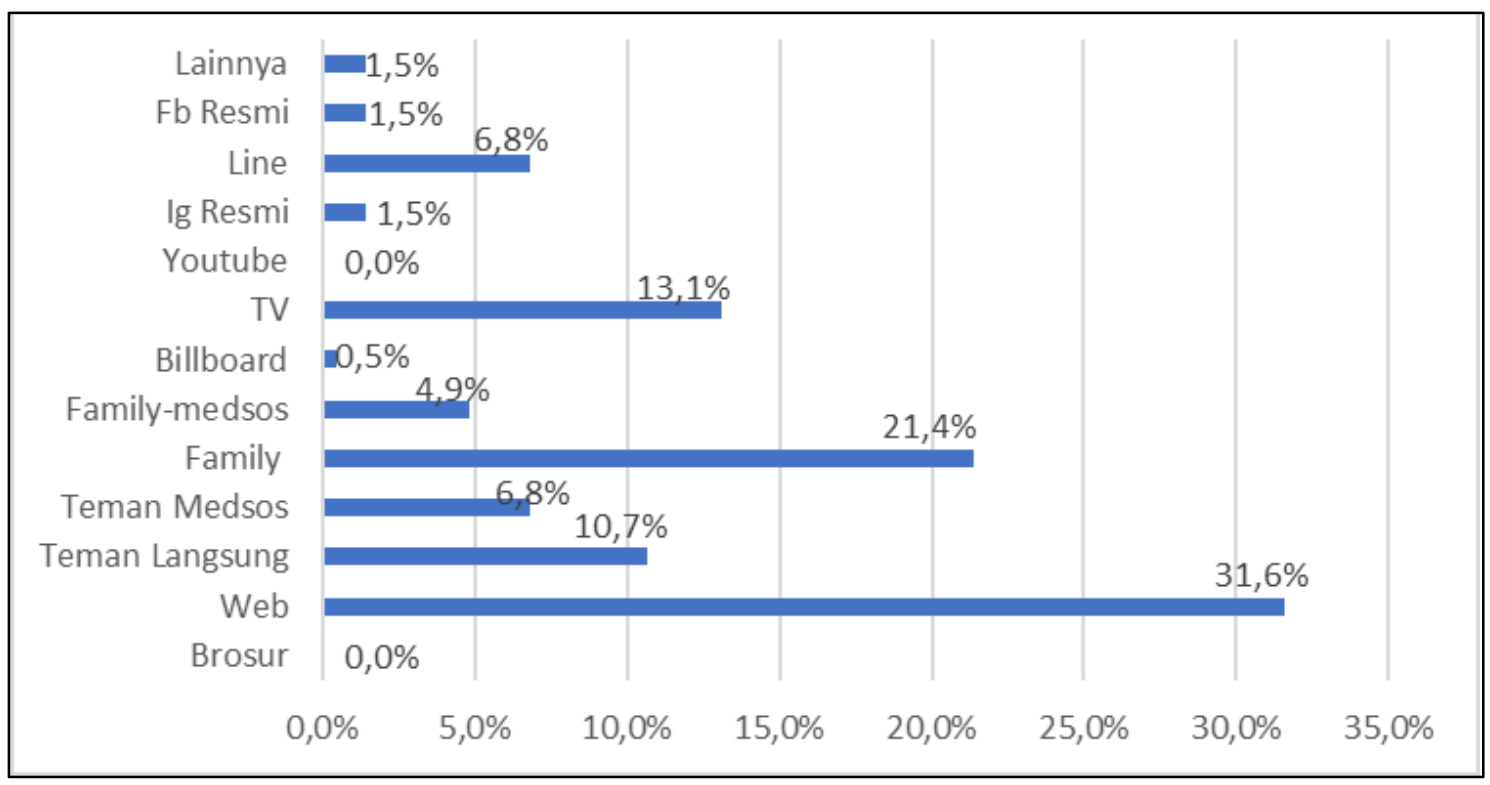

Gambar 10. Hasil Survei Sumber Informasi Iklan Yang di Akses Sumber: Olahan Data Peneliti (2020)

Oleh karena itu, untuk mengikuti perkembangan pencarian informasi melalui web atau internet sudah seharusnya menjadi prioritas, sesuai dengan Rencana Strategi Kementrian Pariwisata (2018-2019) yang mengatakan media promosi saat ini berkembang semakin luas dengan berkembangnya New Media Marketing yang mengacu pada pemanfaatan serangkaian teknik pemasaran modern (berbasis internet) dan penggunaan teknologi informasi yang dinilai lebih efisien tetapi efektif dalam menjangkau segmen pasar yang lebih luas (Kementerian Pariwisata, 2018)

Apabila melihat kembali hubungan pada gambar 6, dengan adanya iklan ternyata meningkatkan pendapatan kunjungan sampai $74 \%-150 \%$, sehingga dapat dikatakan periklanan merupakan aktifitas ekonomi kreatif yang memiliki nilai tambah yang cukup besar. Oleh karena itu dengan tren perkembangan teknologi multimedia seharusnya perkembangan iklan akan semakin meningkat dan pendapatan juga akan meningkat. 
Hal yang perlu dilakukan agar terjadi akselerasi industri pariwisata dan ekonomi kreatif subsektor periklanan terlihat pada prosesnya, orang kreatif periklanan memegang peranan penting agar seluruh aktivitas dalam rantai nilai kreatif berjalan dengan baik. Sebuah karya periklanan dikatakan efektif apabila target (calon pengunjung) mendapatkan pesan sesuai yang diinginkan klien dan pesan dalam iklan tersebut mampu mempengaruhi sikap serta perilaku target market.

Sebagaimana dituliskan oleh Hedriana (2015) tahapan dalam rantai nilai periklanan dibagi ke dalam tiga proses, yaitu kreasi, produksi, dan distribusi. Serta mengacu pada KBLI, bahwa periklanan termasuk kategori jasa profesional, ilmiah, dan teknis, dimana periklanan di Indonesia tidak hanya terbatas pada kegiatan untuk memasarkan produk (product marketing) dan pemasaran sosial (social marketing). Saat ini iklan juga digunakan untuk membangun citra perusahaan atau individu (image marketing), dan kepentingan dalam membangun relasi dengan masyarakat (relation marketing).

Jika perusahaan atau agensi yang dikontrak oleh industri pariwisata dapat beradaptasi dengan prinsip diatas maka diyakinkan akselerasi rantai nilai ini akan semakin memberikan nilai tambah.

Kemudian dengan menganalisa strategi korporat antara Sea World Ancol dengan pelaku Ekonomi Kreatif dalam rantai nilai pariwisata Sea World Ancol, maka hubungan yang terjadi antara KBLI sebagian besar dan khususnya dengan pengusaha penyuplai barang merchandise dilakukan dengan kontrak perjanjian pertahun dengan sistem konsinyasi.

Kontrak perjanjian tersebut merupakan jenis kontrak kerja pendek yang memulai penawaran kompetitif untuk kontrak yang akan diberikan dengan durasi singkat. Manfaat dari pendekatan ini terletak pada buyer seringkali menginginkan harga yang lebih rendah dengan proses penawaran yang kompetitif. Kontrak yang 
dilakukan juga termasuk dalam aliansi strategis, dimana aliansi strategis adalah pengaturan sukarela antara perusahaan yang melibatkan berbagi pengetahuan, sumber daya, dan kemampuan dengan maksud mengembangkan proses, produk, atau layanan. Selain itu, aliansi strategis dapat memfasilitasi investasi dalam aset spesifik transaksi tanpa menghadapi biaya transaksi internal yang terlibat dalam memiliki perusahaan pada berbagai tahap rantai nilai industri (Rothaermel, 2017).

Menurut Hill \& Jones (200) dikatakan bahwa para pihak dalam aliansi berada dalam bisnis yang berbeda tetapi memiliki kepentingan bersama dalam bekerja sama untuk mengembangkan kompetensi khusus dalam penelitian dan pengembangan atau pemasaran yang berguna bagi kedua belah pihak atau memutuskan untuk bekerja sama dalam masalah tertentu, seperti mengembangkan produk atau teknologi baru.

Maka seharusnya produk fesyen dan periklanan yang bekerjasama dengan Sea World Ancol juga harus memiliki rencana pengembangan sebagaimana industri pariwisata, apa yang dapat dilakukan ekonomi reatif ini adalah dengan juga meningkatkan kapasitas usaha mereka, melakukan kreativitas dan inovasi dan tentunya meningkatkan keahlian meraka.

\section{Kesimpulan dan Saran}

\section{Kesimpulan}

Rantai nilai dalam indutri pariwisata salah satu unit di kawasan wisata memiliki nilai tambah dan kegiatan ekonomi kreatif yang bervariasi dengan KBLI yang cukup luas dalam mendukung pendapatan kawasan wisata, dengan beberapa hal penting yaitu: 
1. Sub sektor ekonomi kreatif yang memiliki peran cukup dominan dalam industri pariwisata adalah aktifitas (sub sektor) fesyen, sebagai input produk langsung yang memberikan nilai tambah dalam rantai dan sub sektor ekonomi kreatif periklanan yang berada pada rantai terakhir untuk menyampaikan pesan industri pariwisata kepada konsumen

2. Pencapaian pendapatan kawasan pariwisata meperlihatkan hubungan positif dengan aktifitas ekonomi kreatif, dimana kegiatan ekonomi kreatif fesyen memberikan kontribusi postif terhadap pendapatan dan pengeluaran industri pariwisata dan perusahaan periklanan memberikan korelasi positif terhadap pendapatan wisata.

3. Hasil survei pendapat pengunjung mengambarkan bahwa desain yang unik dan berbeda pada produk fesyen dan periklanan merupakan hal yang dipertimbangkan pengunjung sehingga dapat menjadi salah satu yang harus ditingkatkan agar akselerasi kedepan antara ekonomi kreatif dengan industri pariwisata terus meningkat.

\section{Saran}

1. Rantai nilai yang terbentuk menunjukkan bahwa nilai tambah dan biaya adalah dua faktor utama dan dominan dalam operasional industri pariwisata, maka agar akselerasi rantai nilai dapat terwujud setiap aktifitas ekonomi operasional harus menciptakan nilai tambah dari inovasi produk yang dihasilkan lebih unik dan berkualitas.

2. Sea World Ancol sebagai rantai utama dapat menentukan standar kualitas produk yang diinginkan untuk dipenuhi oleh pemasok produk fesyen maupun perusahaan periklanan. Hasil survei memberi masukan pada kegiatan ekonomi kreatif agar lebih mengembangkan ide produknya. 
3. Pelaku ekonomi kreatif selanjutnya harus meningkatan kreativitas produk yang ditawarkan ke industri pariwisata dengan mempertimbangkan desain yang unik dan menarik sehingga memberikan nilai tambah yang semakin baik pada kegiatan industri utama pariwisata.

4. Penelitian selanjutnya dapat mendalami peranan ekonomi kreatif lain dalam rantai nilai dan dapat mengevaluasi lebih dalam tingkat produktifitas setiap rantai ekonomi kreatif serta membandingkan dengan niali tambah.

\section{Ucapan Terima Kasih}

Puji dan syukur kehadirat Tuhan Yang Maha Esa yang telah melimpahkan rahmat dan hidayah-Nya sehingga penulis dapat menyelesaikan jurnal yang berjudul Peran Ekonomi Kreatif Dalam Meningkatkan Industri Pariwisata Di Seaworld Ancol.

Dalam kesempatan ini, penulis mengucapkan rasa terima kasih yang sebesarbesarnya kepada:

1. Pihak SeaWorld Ancol dan Taman Impian Jaya Ancol yang telah memberikan kesempatan bagi peneliti untuk dapat melangsungkan penelitian dan memperoleh data.

2. Para pengunjung SeaWorld Ancol dan Taman Impian Jaya Ancol yang telah bersedia meluangkan sedikit waktu dalam mengisi pertanyaan dalam quisioner atau survey, pendapat dan penilaian sangat bermanfaat.

Semoga Allah SWT senantiasa membalas semua kebaikan yang telah diberikan, Semoga jurnal ini dapat bermanfaat bagi peneliti dan umumnya kepada para pembaca. 


\section{Daftar Pustaka}

Bekraf. 2017. Data Statistik dan Hasil survey Ekonomi Kreatif: Kerjasam Badan Ekonomi Kreaof dan Badan Pusat Statistik. Jakarta: Bekraf.

Bekraf. 2017. Rencana Strategis Badan Ekonomi Kreatif 2015-2019. Jakarta: Badan Ekonmi Kreatif Indonesia.

BPS. 2019. Lampiran Peraturan Kepala Badan Pusat Statistik Republik Indonesia No. 19 Tahun 2017 Tentang Klasifikasi Baku Lapangan Usaha Indonesia.

DGIP. 2019. Pengenalan Merek. https://dgip.go.id/pengenalan-merek. Direktorat Jenderal Kekayaan Intelektual - Kementerian Hukum dan HAM RI.

APEC. 2019, Agustus. SMEs' Integration into Global Value Chains in Services Industries: Tourism Sector. APEC Committee on Trade and Investment. Mariland: Washington CORE, L.L.C.

Hendriana. E. 2015. Rencana Pengembangan Periklanan Nasional. Jakarta: PT. Republik Solusi.

Kementerian Pariwisata dan Ekonomi Kreatif RI. (2014). Ekonomi Kreatif: Kekuatan Baru Indonesia Menuju 2025. Jakarta: RURU Corps.

Kementerian Pariwisata. 2018. Rencana Strategis 2018-2019. Jakarta: Author.

Kustiani, R. 2019, November 6. Wishnutama: Pariwisata Klop Digabung dengan Ekonomi Kreatif. Tempo.Co. https://travel.tempo.co/read/1268843/wishnutamapariwisata-klop-digabung-dengan-ekonomi-kreatif/full\&view=ok.

Kuswara, U. Sya, A, Waluyo, H, I Gde, P, Cokorda, I, D. 2014. Ekonomi Kreatif: Kekuatan baru Indonesia Menuju 2025. Kementerian Pariwisata dan Ekonomi Kreatif RI: RURU Corps.

Munaf T. 2015. Rencana Strategis Pengembangan Destinasi dan Indutri Paiwisata dan Industri Pariwisata Kementerian Pariwisata Tahun 2015 - 2019. Jakarta: Bekraf.

Munaf. T. 2017. Data Statistik dan Hasil Survei Ekonomi Kreatif. Jakarta: Bekraf.

Munaf, T. 2019. Infografis Sebaran Pelaku Ekonomi Kreatif. Bekraf.

OECD. 2014. Tourism and the Creative Economy. OECD: Paris.

Pembangunan Jaya Ancol. 2018. Laporan Tahunan.Annual Report 2018. https://www.ancol.com/id. 
Rothaermel, F.T. 2017. Strategic Management. NY: Mc. Graw Hill.

Saputra, A. 2019, November 7 UU Diteken Jokowi, Ekonomi Kreatif Harus Berdasarkan Pancasila. DetikNews. https://news.detik.com/berita/d4775165/uu-diteken-jokowi-ekonomi-kreatif-harus-berdasarkan-pancasila.

Pardosi. T. 2018. Jakarta Dalam Angka 2018. Jakarta: Badan Pusat Statistik Provinsi DKI Jakarta.

Rahmah, N. 2019. Apa itu KBLI: Pengertian, Dasar Penyusunan, Fungsi KBLI dan Tips Memilih KBLI yang Tepat. Pengadaan. https://www.pengadaanbarang.co.id/2019/08/kbli-adalah.html

Simanjuntak, D.S. 2017. Snapshot Promosi Produk Kreatif. Jakarta: Bekraf.

Stadler, H. \& Kilger C. 2015. Supply Chain Management and Advanced Planning: Concept, Models, Software, and Case Study. $5^{\text {th }}$ ed. Berlin: Springer-Verlag.

Sutono, A., Rahmono, R, W., Sumaryadi, Puksi, F. 2019. Rencana Strategis Pengembangan Pariwisata halal 2019 - 2024. Jakarta: Kementerian Pariwisata.

Tim Badan Pusat Statistik Provinsi DKI Jakarta. 2018. Jakarta dalam Angka 2018. Jakarta: Badan Pusat Statistik Provinsi DKI Jakarta.

Utoyo, S \& Sutarsih, T. 2017. Profil Usaha/Perusahaan 16 Subsektor Ekra. Badan Pusat Statistik. Jakarta: CV. Dharmaputra.

Widadio, N. A. 2014, 02 April. Menparekraf: Perkembangan Pariwisata Indonesia Paling

Bagus.Kompas.com.http://travel.kompas.com/read/2014/04/02/0949478/Menpar ekraf.Perkembangan.Pariwisata.Indonesia.Paling.Bagus.

World Bank Group. 2018. Jobs in Value Chains Survey Toolkit. Washington: World Bank Publications.

\section{Profil Penulis}

Dewi Retno Dumilah, menyelesaikan program S1 di Fakultas Matematika dan Ilmu Pengetahuan Alam Universitas Indonesia (2001 - 2006), saat ini melanjutkan programpasca sarjana di Magister Manajemen konsentrai Manajemen Operasi, Universitas Mercu Buana tahun ajaran 2019/2020, dan bekerja sebagai Departemen 
Head Operational di Unit Rekreasi Sea World Ancol - Ocean Dream Samudra, Taman Impian Jaya Ancol.

Moh. Komarudin, menyelesaikan program S1 di Fakultas Keguruan \& Ilmu Pendidikan, Pendidikan Bahasa Inggris, Universitas Kuningan (2015), Pernah menempatkan posisi sebagai Wakil 2 Mojang Jajaka Kabupaten Kuningan (2013), saat ini melanjutkan program pascasarjana di Magister Manajemen Universitas Mercu Buana tahun ajaran 2019/2020, dan bekerja sebagai Administrasi Operasional di perusahaan PT Surveyor Indonesia.

Rian Ubaidillah, menyelesaikan program S1 di Fakultas Ekonomi Universitas Mercu Buana Yogyakarta (2011-2015), saat ini melanjutkan programpasca sarjana di Magister Manajemen konsentrai Manajemen Operasi, Universitas Mercu Buana tahun ajaran 2019/2020, dan bekerja sebagai Project Manager di perusahaan creative agency PT. Global Jaring Indonesia.

Sulastri Siagian, menyelesaikan program S1 Statistik di FMipa Innstitut Teknologi Sepuluh November- Surabaya (2009). Saat ini melanjutkan program pascasarjana di Magister Manajemen konsentrsi Manajemen Operasi, Universitas Mercu Buana tahun ajaran 2019/2020. Dan bekerja sebagai Warehouse Manager di Perusahaan Aksesoris PT. Bintang Hartono Jaya.

Dr. Ir. Sugeng Santoso, MT. menyelesaikan program S1 di Universitas Brawijaya (1991), program S2 di Institut Teknologi Bandung (1997), dan Program Doktoral di Universitas Brawijaya (2004). Saat ini selain sebagi dosen pascasarjana Universitas Mercu Buana juga pernah menjabat sebagai Direktur Akses Non Perbankan Badan Ekonomi Kreatif (BEKRAF), Ketua Tim Renstra BEKRAF 2015-2019 dan sekarang menjabat sebagai Staf Ahli Menteri Bidang Ekonomi Maritim Kementerian Koordinator Bidang Kemaritiman dan Investasi. 